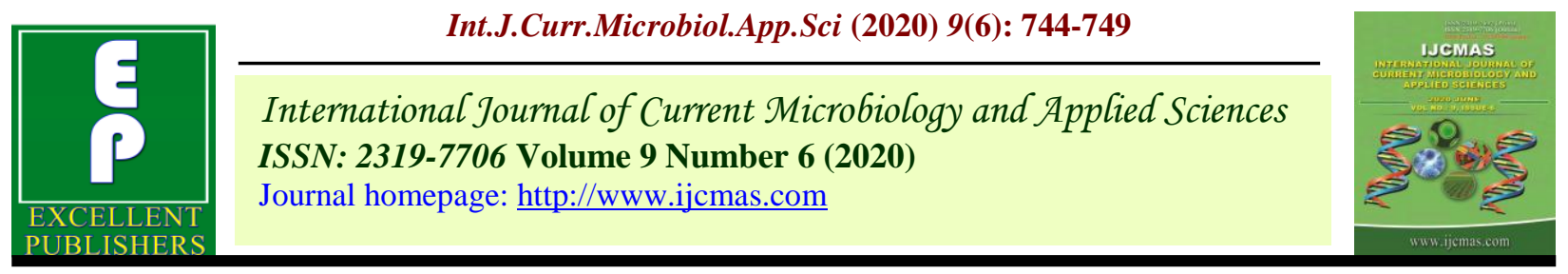

Original Research Article

https://doi.org/10.20546/ijcmas.2020.906.095

\title{
Identification of Suitable Pearl Millet (Pennisetum glaucum L.) Hybrids with Optimum Dose of Nitrogen for Higher Yield under Summer Sown Condition of Southern Telangana
}

\author{
Alok Singh Jayara* and A. Pratap Kumar Reddy \\ ${ }^{1}$ Department of Agriculture, Him giri Zee University, Dehradun, India \\ ${ }^{1}$ College of Agriculture, Rajendranagar, Professor Jayashankar Telangana State Agriculture \\ University (Formerly ANGRAU), Hyderabad 500030, India
}

\begin{tabular}{l} 
K e y w o r d s \\
Pearl millet \\
Hybrids, Levels of \\
nitrogen, Split Plot \\
Design, Number of \\
spikes per ${ }^{2}$, Spike \\
length, Grain \\
weight, Test weight, \\
Grain yield \\
Article Info \\
$\begin{array}{l}\text { Accepted: } \\
\text { 15 May } 2020 \\
\text { Available Online: } \\
\text { 10June } 2020\end{array}$ \\
\hline
\end{tabular}

Keywords

Pearl millet

Hybrids, Levels of

nitrogen, Split Plot

spikes per $\mathrm{m}^{2}$, Spike

length, Grain

weight, Test weight,

Grain yield

Article Info

Accepted:

15 May 2020

10June 2020

\section{A B S T R A C T}

A field Study on response of three pearl millet hybrids to the four levels of nitrogen was conducted at College farm, College of Agriculture, Rajendranagar, Hyderabad during the summer season of 2010-11. The study comprised of three hybrids Vikas, Hanuman and XB-20plus at four levels of nitrogen $\left(0,40,80,120 \mathrm{kgha}^{-1}\right)$. The design of experiment was split plot design with hybrids as main plot treatments and the levels of nitrogen as sub-plot treatments. Analysis was carried out for grain yield and yield contributing factors i.e. number of spikes per $\mathrm{m}^{2}$, spike length, grain weight. It was concluded that all the mentioned yield attributing characters except test weight, were superior with hybrid Hanuman (Test weight was found to be at par with all three hybrids). These yield attributing characters including test weight was found superior with the level of $120 \mathrm{~kg} \mathrm{~N} \mathrm{ha}^{-1}$. Grain yield was recorded highest with hybrid Hanuman over the other two hybrids and among the nitrogen levels, it was with application of $120 \mathrm{~kg} \mathrm{~N}$ ha $^{-1}$.

\section{Introduction}

Pearl millet is an important food crop of the arid and semi-arid regions in India. It is well adapted to the harsh climates characterized by less rainfall and higher heat. It can be owed to its $\mathrm{C}_{4}$ photosynthetic pathway, however, its efficiency of soil moisture utilization and degree of heat tolerance is higher than the contemporary $\mathrm{C}_{4}$ crops like maize and sorghum. Thus, the crop can be an important part of crop rotation in summer season. The grain of pearl millet contains 11.31-19.62 per cent protein, 35.69 per cent starch, 2-2.7 per cent total sugar, 3-4.6 per cent fats and good amount of phosphorous and iron. In India, this crop is grown in an area of 8.73 million hectares and production of 8.89 million tones 
with a productivity of $1018 \mathrm{~kg} \mathrm{ha}^{-1}$ (CMIE, 2010). The major pearl millet growing states in India are Rajasthan, Maharashtra, Gujarat, Uttar Pradesh, Haryana, Karnataka, Tamil Nadu, Madhya Pradesh and Andhra Pradesh. In Andhra Pradesh, it is grown in an area of 0.06 million hectare with production of 0.06 million tones with a productivity of $1000 \mathrm{~kg}$ $\mathrm{ha}^{-1}$ (CMIE, 2010).

Pearl millet is most suited for the summer season in arid and semi-arid regions due to its ephemeral nature and higher degree of heat tolerance. The choice of variety/hybrid is an important prerequisite for the higher yields. The soils of arid and semi-arid regions are inherently deficit in organic carbon due to increased rate of decomposition of organic matter owing to higher temperature. Considering the important relationship between the organic matter and nitrogen, it can be concluded that these soils are deficient in nitrogen too. Recent studies have shown that newly developed hybrids of pearl millet are more responsive to the nitrogenous fertilizers. The full exploitation of hybrid vigour and economizing the each incremental dose of nitrogen are equally important at farmer's field. The southern region of Telangana state presents the optimum climatic conditions for summer pearl millet crop and it forms the important component of cereal system.

\section{Materials and Methods}

A field experiment was conducted on the College farm, College of Agriculture, Rajendranagar, Professor Jayashankar Telangana State Agriculture University (Formerly ANGRAU), Hyderabad during the summer season of 2010-11. The soil of the experimental site was sandy clay loam, slightly alkaline in reaction, low in organic carbon, low in nitrogen and high in available phosphorous and medium in available potassium. The experiment was conducted with split plot design with three main plot treatments comprising of three hybrids i.e. H1: Vikas; H2: Hanuman and H3: XB-20plus and sub-plot treatments with four graded levels of nitrogen i.e. N1: $0 \mathrm{kgha}^{-1}$; N2: 40 $\mathrm{kgha}^{-1}$; N3:80 $\mathrm{kgha}^{-1}$ and N4:120 $\mathrm{kgha}^{-1}$. Thus, there were twelve treatment combinations. The experiment consisted of three replications.

The recommended dose of nitrogen fertilizer is $80 \mathrm{kgNha}^{-1}$. Hybrid Vikas (H1) is having duration of 75 days with yield potential of 20$25 \mathrm{qha}^{-1}$. Hybrid Hanuman (H2) is having duration of 85 days with yield potential of 2530 qtha $^{-1}$ and that of hybrid XB-20plus is of 78-80 days duration with yield potential of 20-25 qtha ${ }^{-1}$.

The tillage practices were as per the local one with one tractor drawn cultivator followed by animal drawn harrow. The seeds were sown at spacing of $45 \mathrm{cms} \times 15 \mathrm{cms}$ with depth of 2-3 cms. Nitrogen was applied in split i.e. $1 / 2$ at sowing and $1 / 2$ at 30 DAS and phosphorous and potassium were applied as basal @ $40 \mathrm{~kg}$ P2O5 ha ${ }^{-1}$ and $30 \mathrm{~kg} \mathrm{~K} 2 \mathrm{O} \mathrm{ha}^{-1}$, respectively. Irrigation were applied with first two after 10 and $20 \mathrm{DAS}$, and the rest at the interval of 7 days. Atrazine @ $1.0 \mathrm{~kg}$ ai ha ${ }^{-1}$ was applied as pre-emergence and manual weeding at 30 DAS. The data recorded was statistically analyzed with the ANOVA technique for split plot design as suggested by Panse and Sukhatme (1978) at 5 per cent level of significance.

\section{Results and Discussion}

\section{Yield attributes}

Four yield attributes were analysed i.e. number of spikes $\mathrm{m}^{-2}$; spike length; grain weight per spike and test weight. The effect of hybrids and levels on yield attributes was found significant, however, their interaction effect was found non-significant (Table 1). 
Number of spikes $\mathrm{m}^{-2}$, spike length and grain weight per spike was found to significantly higher for hybrid Hanuman (H1), followed by hybrid XB-20 plus and significantly lower in hybrid Vikas (H1). However, the test weight was found to be constant for all the three. The results were in confirmation with Bar et al., (1988), Sharma et al., (1999), Kumar et al., (2004) and Pathan et al., (2010) (Table 1).

Each incremental dose of nitrogen from $0 \mathrm{~kg}$ $\mathrm{ha}^{-1}$ to $120 \mathrm{~kg} \mathrm{ha}{ }^{-1}$ has seen significant increase in the yield attributing character. 120 $\mathrm{kg} \mathrm{N} \mathrm{ha}{ }^{-1}$ has reported the highest yield attributes in range of 45.6 per cent for number of spikes $\mathrm{m}^{-2} ; 55$ per cent for spike length; 78.7 per cent for grain length and 21 per cent for test weight. Among all the yield attributes, test weight has seen the least increase. This can be attributed to its determination by genetic potential. The results were in confirmation with Sharma et al., (1999) and Yakadari and Reddy (2009).

Table.1 Effect of different pearl millet hybrids and nitrogen levels on the spike length $(\mathrm{cm})$, number of spikes m-2, 1000 grain weight $(\mathrm{g})$ and grain weight per ear $(\mathrm{g})$

\begin{tabular}{|c|c|c|c|c|}
\hline Treatment & $\begin{array}{l}\text { Spike length } \\
\text { (cm) }\end{array}$ & $\begin{array}{c}\text { Number of spikes } \\
\mathbf{m}^{-2}\end{array}$ & $\begin{array}{l}1000 \text { grain weight } \\
\text { (g) }\end{array}$ & $\begin{array}{c}\text { Grain weight per } \\
\text { ear (g) }\end{array}$ \\
\hline \multicolumn{5}{|c|}{ Hybrids } \\
\hline Vikas (H1) & 18.4 & 31.0 & 7.7 & 14.7 \\
\hline $\begin{array}{l}\text { Hanuman } \\
\text { (H2) }\end{array}$ & 22.2 & 40.0 & 8.2 & 19.0 \\
\hline XB 20 plus & 19.9 & 36.0 & 7.8 & 16.4 \\
\hline SEm \pm & 0.25 & 0.60 & 0.21 & 0.13 \\
\hline $\mathrm{CD}(\mathrm{P}=\mathbf{0 . 0 5})$ & 0.97 & 2.30 & NS & 0.52 \\
\hline \multicolumn{5}{|c|}{ Nitrogen levels $\left(\mathrm{kgha}^{-1}\right)$} \\
\hline $\mathbf{0}$ & 15.8 & 28.7 & 7.1 & 12.2 \\
\hline 40 & 18.6 & 33.7 & 7.6 & 15.0 \\
\hline 80 & 21.7 & 38.5 & 8.1 & 17.8 \\
\hline 120 & 24.5 & 41.8 & 8.6 & 21.8 \\
\hline SEm \pm & 0.49 & 0.53 & 0.12 & 0.22 \\
\hline$C D(P=0.05)$ & 1.45 & 1.60 & 0.26 & 0.64 \\
\hline \multicolumn{5}{|c|}{ Interaction $(\mathbf{H} \times \mathbf{N})$} \\
\hline \multicolumn{5}{|c|}{ Sub at same main } \\
\hline SEm \pm & 0.49 & 1.2 & 0.22 & 0.26 \\
\hline $\mathrm{CD}(\mathbf{P}=0.05)$ & NS & NS & NS & NS \\
\hline \multicolumn{5}{|c|}{ Main at same or different sub } \\
\hline SEm \pm & 0.77 & 1.0 & 0.38 & 0.35 \\
\hline CD $(P=0.05)$ & NS & NS & NS & NS \\
\hline
\end{tabular}


Table.2 Effect of different pearl millet hybrids and nitrogen levels on grain yield $\left(\mathrm{kg} \mathrm{ha}^{-1}\right)$, stover yield $\left(\mathrm{kgha}^{-1}\right)$ and harvest index (per cent)

\begin{tabular}{|c|c|c|c|}
\hline Treatment & grain yield $\left(\mathrm{kg} \mathrm{ha}^{-1}\right)$ & stover yield $\left(\mathrm{kgha}^{-1}\right)$ & harvest index (per cent) \\
\hline \multicolumn{4}{|c|}{ Hybrids } \\
\hline Vikas (H1) & 1530 & 4396 & 34.4 \\
\hline $\begin{array}{c}\text { Hanuman } \\
\text { (H2) }\end{array}$ & 2067 & 5102 & 40.1 \\
\hline XB 20 plus & 1809 & 4678 & 38.3 \\
\hline SEm \pm & 76.7 & 63.5 & 0.99 \\
\hline $\mathrm{CD}(\mathbf{P}=0.05)$ & 221.6 & 170.0 & 3.80 \\
\hline \multicolumn{4}{|c|}{ Nitrogen levels (kgha-1) } \\
\hline $\mathbf{0}$ & 1260 & 4273 & 29.4 \\
\hline 40 & 1629 & 4506 & 36.0 \\
\hline 80 & 1879 & 4760 & 39.5 \\
\hline 120 & 2439 & 5361 & 45.4 \\
\hline SEm \pm & 57.0 & 86.4 & 1.3 \\
\hline $\mathrm{CD}(\mathrm{P}=0.05)$ & 169.3 & 257.0 & 3.8 \\
\hline \multicolumn{4}{|c|}{ Interaction $(\mathrm{H} \times \mathrm{N})$} \\
\hline \multicolumn{4}{|c|}{ Sub at same main } \\
\hline SEm \pm & 113.5 & 87.0 & 1.98 \\
\hline $\mathrm{CD}(\mathbf{P}=\mathbf{0 . 0 5})$ & NS & NS & NS \\
\hline \multicolumn{4}{|c|}{ Main at same or different sub } \\
\hline SEm \pm & 102.6 & 136.6 & 2.18 \\
\hline $\mathrm{CD}(\mathrm{P}=0.05)$ & NS & NS & NS \\
\hline
\end{tabular}

\section{Grain yield}

Grain yield for all the three hybrids differed significantly with highest being reported in Hybrid Hanuman (H2). The mean yield of this hybrid was recorded at $2067 \mathrm{kgha}^{-1}$, which was 14.4 per cent and 35.5 per cent higher when compared to hybrid XB 20 plus (H3) and Hybrid Vikas (H1), respectively. The yield enhancement was attributed to significantly higher number of yield attributing characters. The results were in confirmation with Mohammad (1998), Satyajit et al., (2007), Rathore et al., (2008) and Pathan et al., (2010) (Table 2).

This was continuous and significant enhancement of yield levels with each increased dose of nitrogen from $40 \mathrm{~kg} \mathrm{ha}^{-1}$ to
$120 \mathrm{~kg} \mathrm{ha}^{-1}$, with maximum at $120 \mathrm{~kg} \mathrm{~N} \mathrm{ha}^{-1}$. The maximum enhancement of yield was recorded with 29.8 per cent between $80 \mathrm{~kg} \mathrm{~N}$ $\mathrm{ha}^{-1}$ to $120 \mathrm{~kg} \mathrm{~N} \mathrm{ha}^{-1}$, followed by 29 per cent between $0 \mathrm{~kg} \mathrm{~N} \mathrm{ha}^{-1}$ to $40 \mathrm{~kg} \mathrm{~N} \mathrm{ha}^{-1}$, and 15.3 per cent between $40 \mathrm{~kg} \mathrm{~N}^{-1}$ to $80 \mathrm{~kg} \mathrm{Nha}^{-1}$. The results were in confirmation with Mohammad (1998), Sehwag et al., (2003), Kumar et al., (2004) and Girase et al., (2010) (Table 2).

\section{Stover yield (kgha-1)}

The stover yields were in accordance with the grain yield i.e. Hybrid Hanuman (H2) was significantly superior to other two hybrids, and hybrid XB 20 plus (H3) was significantly superior to hybrid Vikas (H1). Hybrid Hanuman put forth significant stover yields 
with 18.6 and 8.97 per cent when compared to hybrid Vikas (H1) and hybrid XB 20 plus (H3), respectively. The results were in confirmation with Bar et al., (1988), Sharma et al., (1999) and Kumar et al., (2004) (Table 2).

The results indicated the application of increased levels of nitrogen from $0 \mathrm{~kg} \mathrm{ha}^{-1}$ to $120 \mathrm{~kg} \mathrm{ha}^{-1}$ progressively increased the stover yield significantly. The maximum difference of $1088 \mathrm{~kg} \mathrm{~N} \mathrm{ha}^{-1}$ was noticed with $120 \mathrm{~kg} \mathrm{~N}$ $\mathrm{ha}^{-1}$ when compared with $0 \mathrm{~kg} \mathrm{~N} \mathrm{ha}{ }^{-1}$. The results were in confirmation with Vyas et al., (1992) and Sehwag et al., (2003) (Table 2).

\section{Harvest Index (Per cent)}

Hybrid Hanuman (H2) recorded significantly higher harvest index (i.e. 40.1 per cent) over hybrid Vikas (H1), however, the same was at par with hybrid XB 20 plus (H3). The difference among the hybrids can be attributed to the difference in assimilate partitioning efficiency of hybrids. The results were in confirmation with Yadav et al., (2004) (Table 2).

There was significant increase in harvest index from $0 \mathrm{~kg} \mathrm{~N} \mathrm{ha}^{-1}$ to $120 \mathrm{~kg} \mathrm{~N} \mathrm{ha}^{-1}$, except when it was enhanced between $40 \mathrm{~kg}$ $\mathrm{N} \mathrm{ha}^{-1}$ to $80 \mathrm{~kg} \mathrm{~N} \mathrm{ha}^{-1}$ (Table 2).

Hybrids have the potential to surpass the yield levels of the traditional and improved varieties. However, their potential can be achieved with optimum nutrition. In dryland tracts, the deficiency of nitrogen is the most common. From the above study, now it can be concluded that the hybrid $\mathrm{H} 2$ (Hanuman) with nitrogen dose $120 \mathrm{~kg} \mathrm{ha}^{-1}$ is the most suitable of the southern Telangana region.

\section{References}

Bar, A. K., Gautam, R. C. and Kaushik, S. K. 1988 Response of pearlmillet genotypes in sole and intercropping systems under rainfed conditions. Indian Journal of Agronomy 33(1): 52-55.

CMIE, 2010. Centre for Monitoring of Indian Economy, Annual Report, Centre for Monitoring Indian Economy Private Limited. Mumbai.

Girase, P., Wadia, S.C., Sonawane, P.D., Chaudhari, P.M., and Chitodkar, S. S. 2010. Nutrient management for Pearl millet (Pennisetum glaucum L.) in light soils of rainfed areas. Journal of Maharashtra Agriculture University 35 (1): 007-009.

Kumar, S., Kadian, V. S. and Singh, R. C. 2004. Response of Pearl millet (Pennisetum glaucum L.) hybrids to row spacing and nitrogen application. Annals of Agricultural Research 25(1): 68-70.

Mohammad, S. 1998. Production response and economics of nitrogen application rates to pearlmillet varieties scarce rainfall-shallow soil eco systems. Crop Research 16(1): 17-19.

Pathan, S. H., Bhilare, R. L. and Damame, S. V., 2010. Seed yield of forage pearl millet varieties as influenced by nitrogen levels under rainfed conditions. Journal of Maharashtra Agriculture Research 35(2): 306-308.

Rathore, B. S., Rana, V. S. and Nanwal, R. K. 2008. Effect of plant density and fertility levels on growth and yield of pearl millet (Pennisetum glaucum L.) hybrids under limited $\mathrm{n}$ semi-arid environment. Indian Journal of Agricultural Sciences 78 (8): 667-670.

Satyajeet, Nanwal, R. K., Yadav, V. K. and Kumar, P. 2007. Effect of integrated nutrient management on productivity of pearlmillet (Pennisetum glaucum L.) and its residual effect on mustard (Brassica juncea) Haryana Agriculture University Journal of Research 37: 1518. 
Sehwag, M., Singh, H., Hooda, R. S. and Khippal, A. 2003. Response of pearl millet (Pennisetum glaucum L.) composites to nitrogen under rainfed conditions. Crop research 26(1): 67-70.

Sharma, P. K., Yadav, G. L., Frageria, V. D., Kumar, S. and Sharma, S. L. 1999. Rresponse of pearl millet (Pennisetum glaucum $L$.) varieties to different levels of nitrogen under late-sown rainfed conditions. Indian Journal of Agronomy 44(4): 765-767.

Vyas, S. H., Patel, J. C., Patel, B. S. and Sukhadia, N. M. 1992. Response of summer pearl millet (Pennisetum glaucum L.) to irrigation, nitrogen and phosphorous. Indian Journal of Agronomy 37(4): 819-821.

Yadav, Y., Kumar, A., and Singh, B. 2004. Comparative performance of pearl millet hybrids and composites under rainfed conditions. Haryana Agriculture University Journal of Research 34: 4547.

Yakadari, M. and Reddy, A. P. K. 2009. Productivity of pearl millet (Pennisetum glaucum L.) as influenced by planting pattern and nitrogen levels during summer. Journal of Research, ANGRAU, 37 (1\&2): 34-37.

\section{How to cite this article:}

Alok Singh Jayara and Pratap Kumar Reddy, A. 2020. Identification of Suitable Pearl Millet (Pennisetum glaucum L.) Hybrids with Optimum Dose of Nitrogen for Higher Yield under Summer Sown Condition of Southern Telangana. Int.J.Curr.Microbiol.App.Sci. 9(06): 744749. doi: https://doi.org/10.20546/ijcmas.2020.906.095 